Greer, C. and McLaughlin, E. (2016) 'Theorising Institutional Scandal and the Regulatory State', Theoretical Criminology, xxx

\title{
Theorising Institutional Scandal and the Regulatory State
}

\begin{abstract}
One by one, UK public institutions are being scandalised for corruption, immorality or incompetence and subjected to trial by media and criminal prosecution. The state's historic response to public sector scandal - denial and neutralisation - has been replaced with acknowledgement and regulation in the form of the re-vamped public inquiry. Public institutions are being cut adrift and left to account in isolation for their scandalous failures. Yet the state's attempts to distance itself from its scandalised institutions, while extending its regulatory control over them, are risky. Both the regulatory state and its public inquiries risk being consumed by the scandal they are trying to manage.
\end{abstract}

Key words: scandal; intermediatisation; public inquiry; risk, regulatory state; trial by media

\section{Introduction}

The UK is experiencing a proliferation of public sector institutional scandals. Following a succession of scandals involving the banking sector (Ashton \& Christophers, 2015), politicians' expenses (Pattie \& Johnston, 2012), state surveillance (Salter, 2015), and phonehacking by journalists (Keeble \& Mair, 2012), Britain's public institutions - the BBC, the National Health Service, the police, the Crown Prosecution Service, schools and colleges, local authorities, and Parliament - have all been implicated in institutional child sex abuse scandals. In response to this proliferation of public sector scandals, there has been an increase in public inquiries. The Independent Inquiry into Child Sexual Abuse (IICSA), triggered by the multi-institutional Sir Jimmy Savile scandal and a raft of associated investigations, was established in 2015. Led by Justice Lowell Goddard, this public inquiry's remit exceeds that of any in British history. Its purpose is to establish the extent to which 'institutions have failed in their duty of care to protect children from sexual abuse and exploitation; to consider the extent to which those failings have since been addressed; to 
identify further action needed to address any failings identified; to consider the steps which it is necessary for State and non-State institutions to take in order to protect children from such abuse in future; and to publish a report with recommendations' (https://www.iicsa.org.uk/about-us/terms-of-reference, accessed $26^{\text {th }}$ February 2016). It will also examine allegations of child sexual abuse involving public figures. Though the IICSA's remit is expansive and includes both state and non-state institutions, its origins lie firmly in the public sector. It was established in response to 'increasing reports of child sexual abuse in a number of institutions, including in the BBC, the NHS, in children's homes and in schools', and 'growing reports of failures within the police to investigate allegations of child sexual abuse, and failures within the Crown Prosecution Service to prosecute these allegations' (https://www.csa-inquiry.independent.gov.uk/about-the-inquiry/background, accessed $26^{\text {th }}$ February 2016). The inquiry timeframe is equally ambitious and will consider allegations of child sexual abuse dating back to 1945 . The inquiry is expected to publish the final report around 2020. Simultaneous and separate public inquiries into institutional child sexual abuse have been established in Northern Ireland and Scotland.

Scandal has become a key mechanism used by news media, pressure groups and social movements to demand inquiries and investigations into alleged corruption, incompetence and immorality. Yet despite its growing prevalence and, as we argue in this article, its escalating significance and impact, scandal has received little attention from sociologists, and still less from criminologists. This neglect is surprising since, by definition, scandals are intertwined with flows and abuses of official power and are key to governance and social order. Existing research indicates that scandals can have a corrosive impact on the reputational standing, credibility and legitimacy of institutions and contribute to a pervasive climate of suspicion in institutional and political elites (Davis, 2006; Garment, 1991; Moore, 1995; Seldon, 2009; Thompson, 2000; Tiffen, 1999). In this article we develop an analysis of institutional scandal and the state reaction to scandal proliferation that builds on Blumer's (1986: 19) defining statement on symbolic interactionism:

A network or an institution does not function automatically because of some inner requirements or system dynamics; it functions because people at some point do something, and what they do is a result of how they define the situation in which they are called on to act... It is necessary to recognise that the sets of meanings that lead 
participants to act as they do at their stationed points in the network have their own setting in localized process of social interaction and that these meanings are formed, sustained, weakened, strengthened or transformed, as the case may be, through a socially defining process. Both the functioning and the fate of institutions are set by this process of interpretation as it takes place among the diverse sets of participants.

It is our contention that institutional scandal proliferation and the state response to it have been transformed, and that both sides of this interactional dynamic - shaped by processes of interpretation and the resultant actions of diverse sets of participants - require analytical attention. Further, we argue that such an analysis, in addition to elucidating the workings, significance and impact of institutional scandal, offers insights into the ongoing reconfiguration of the relationship between citizen-consumers, the news media, public institutions and the regulatory state.

The article proceeds as follows. First, we summarise existing research on the significance and impact of scandal to provide context for our analysis. Next, building on this literature and our own previous work (Greer \& McLaughlin, 2012a, 2012b, 2013, 2015), we set out our process model of how contemporary institutional scandals activate and unfold. Thereafter, we extend our analysis to the under-researched area of the state's reaction to scandal. Considering the significance and impact of UK public sector scandal proliferation, we propose that the regulatory state's growing readiness to establish public inquiries - the IICSA being the most far-reaching example - is at once politically calculated and inherently risky. In the concluding section, we argue that analysing the activation and amplification of public sector scandals, and attempts to manage the scandal machine through the public inquiry, illustrates the contradictory logics of the regulatory state.

\section{The Significance and Impact of Scandal}

It is within US political science that most attention has been given to researching the significance and impact of scandals. This literature is characterised by case studies of highprofile executive scandals involving elite individuals, with Watergate still standing as the key reference point (Dagnes, 2011; Davis, 2006; Entman, 2012; Garment, 1991; Ginsberg \& Shefter, 1999; Rottinghaus, 2015; Rozell \& Wilcox, 2000; Sabato et al., 2000). Media and 
communications scholars have tended to conceptualise scandal as a distinctive mode of tabloid infotainment, and focus primarily on celebrity scandals (Lull \& Hinerman, 1997; Petersen, 2012). Among criminologists, Sherman (1978) has produced the only book-length analysis of scandal, relating to police corruption and reform. Most recently, Pratt (2008) has examined the capacity of scandal to threaten the legitimacy of systems of power, connecting them with the rise of penal populism as government's try to win back public trust and confidence. Thompson (2000) and Castells (2009) have produced the most developed sociological analyses of mediated scandals. All contemporary scandals are by definition mediated since, as Thompson puts it, they are 'literally played out in the media and the activities of media personnel and organisations, with their distinctive practices and rhythms of work, play a crucial role' (2000. p.74). Scandals have become a prized news commodity, it is proposed, because of their capacity to: generate financial gains through increased audiences; advance political agendas; validate the professional 'watchdog' conception of investigative journalism; and allow news agencies to outdo their rivals. The result has been the creation of a distinctive scandal news market serviced by an industry of stakeholders and potential beneficiaries searching for scandalous stories, photographs and video footage. The commercial value of this market means that news agencies, irrespective of their target audience or ideological orientation, have little choice but to join in with the reporting of a high-profile breaking scandal. Thus corporate news media are now locked into a mode of reporting that amplifies scandals' prominence still further (Entman, 2012; Lull \& Hinerman, 1997; Sabato et al., 2000; Thompson, 2000). Research indicates that US executive scandals have tended to be reported in the news media as exceptional and individualised incidents of corruption, incompetence or immorality by 'bad apples' within a system that is otherwise deemed broadly sound. Much work on scandal has supported Hallahan's (1999: 220) general point that people tend to 'attribute problems to corrupt, inept, or irresponsible individuals. The result is to ignore systemic problems related to social organisation or societal resources available to deal with a problem'. For many scandologists the exposure of scandalous transgressions reaffirms for citizens 'that the process does work, that it does curtail the arbitrary exercise of political power, and that the political system by and large deserves the support and loyalty of all citizens' (Markovits \& Silverstein, 1988: 9). Thus, in classic functionalist fashion, 'the resolution of a scandal's challenge to the system is a reaffirmation and strengthening of the public's faith in that system' (ibid: 9). Recent US 
research on executive scandals acknowledges their potentially deleterious effects, but ultimately still finds that they have little lasting impact on a resilient political process:

The system... bends but does not break in the aftermath of these crises; it maintains good health and is responsive in predictable ways. The system reacts to investigate and admonish further wrongdoing in the aftermath of scandals: More legislative hearings are held to probe wrongdoing and more investigations by external and internal agencies are conducted. Ultimately, the institutional ramifications for executive scandals demonstrate impressive adaptability of the actors involved and the system at large' (Rottinghaus, 2015: 4).

Thompson (2000) acknowledges the positive potential of scandals to raise important questions about the acquisition, uses and abuses of political power and the structures of accountability that seek publicly to regulate those who exercise such power. He also notes that 'a major political scandal, or a series of lesser but cumulatively significant scandals, can help to create a culture of deepening distrust' among sections of the population who may be 'inclined to distrust not just particular leaders or potential leaders, but politicians per se' (Thompson, 2000: 256). Thus counter to functionalist readings of US executive scandals, Thompson identifies the potential for a longer-term threat to the legitimacy of the liberal democratic process.

Thompson's is a more holistic consideration of the potential cumulative impact of scandal proliferation. However, his conceptualisation of mediated scandals predates the rise of social media and does not address the processes of intermediatisation - the viral interaction within and between corporate and social media - with which were are concerned in this article. In this pre-digital media context, scandals are temporally constrained. They can develop over a period of time but 'cannot continue indefinitely' because every scandal will 'either reach a point of termination (a confession, a resignation, the outcome of a trial, the result of an official inquiry etc.) or it will gradually fade out, as public interest wanes and media organisations decide that it no longer merits the attention once devoted to it' (Thompson, 2000: 72). Recent changes to this media context have shattered these temporal constraints. Situating scandals within global communication networks, Castells (2009: 242; 247-248) identifies three important trends: first, the shift to news as infotainment elevates scandal to a prime, audience-grabbing news product; second, the corporate media 
development of online platforms facilitates the rapid dissemination of scandal news to global audiences; third social media can be used by a variety of actors and interest groups to disseminate scandalous allegations. The result according to Castells (2009: 254) is the emergence of a scandal politics that is contributing to 'a worldwide crisis in political legitimacy'.

While Thompson's and Castells' work has been instructive in developing our analysis of institutional scandal, neither considers how scandal proliferation is affecting state practice. For us this question is pivotal. Both spend time defining the political arena of liberal democracy and situating the activities of political actors, institutions and media within it. Yet while institutions and the state are referred to periodically, their analyses focus primarily on the plight of elite individuals who become embroiled in scandals, and on the possible consequences of scandal proliferation for public trust in politicians and the political process. We feel it is crucial also to theorise and research scandals at the level of state institutions, and to analyse the consequences of institutional scandals for contemporary modes of governance.

Butler and Drakeford's (2005) research is insightful in this regard. Their constructionist analysis of post-War UK welfare scandals examines the role of claimsmakers in scandal generation, and the impact of those scandals on social policy. They identify the public inquiry as the critical interface between welfare scandals and the British state, and the key mechanism driving policy reform. It is argued that although inquiry reports are supposed to produce the definitive account of a scandal, they are in fact the result of a social process, layering one more voice on a highly contested definitional terrain. Their analysis of the public inquiry as the state response to welfare scandals, and the wider policy and political contexts out of which scandals arise and are understood, stops short of considering the changing mode of governance that shapes those contexts. Developing such an analysis is one aim of this article. Furthermore, while Butler and Drakeford recognise that the news media are key to the process of contestation through which scandals are framed for a mass audience, their case-studies, like Thompson's, all predate recent developments in communication technologies and 'the media' here means the printed press. Butler and Drakeford are not concerned with processes of intermediatisation in the activation, amplification and viral dissemination of scandal. As with much of the US political science 
literature, individual scandals are bracketed-off and examined in their own historical and policy context. This case-study approach limits consideration both of the amplification of scandals across different institutions and the interaction between different scandals over time.

Building on the above literatures and our own ongoing empirical research, we develop an interactionist analysis of institutional scandal that considers the intermediatised context within which all such scandals now activate and unfold, the state response to scandal proliferation, and the impact of institutional scandal on contemporary governance. In the next section, we set out our conceptualisation of institutional scandal.

\section{Inside the Institutional Scandal Machine}

Institutional scandals clearly have a structure, but we do not view them primarily in structural terms. Rather we conceptualise institutional scandal as a process. Here we map out and describe some of the phases and characteristics that institutional scandals appear to share (see Figure 1). We stop short of proposing that our conceptualisation is fixed, still less deterministic, and are cautious about overgeneralisation. Our process model is intended as a guide to further empirical research so that it might be refined, challenged and improved across a variety of situations and contexts. Our aims in developing the following process model are: to identify what we see as the default position of many corporate news and social media outlets today - scandal hunting - and to systematically work through the subsequent phases of contemporary institutional scandals - latency, activation, reaction, amplification and accountability; and to analyse the transforming role of corporate news and social media in each of these phases, and the driving impact of 'trial by media'. We remain mindful of Blumer's (1986: 20) caution that, 'One is on treacherous and empirically invalid ground if he thinks that any given form of joint action can be sliced off from its historical linkage, as if its makeup and character arose out of the air through spontaneous generation instead of growing out of what went before'. For this reason, we are concerned also to demonstrate the interaction between 'individual' and the 'institutional' dynamics in the development of institutional scandals, and to illustrate the interaction not only between 
different phases of a particular scandal, but between different institutions caught up in the viral process of scandal amplification and between different scandals over time.

Insert Figure 1 about here

\section{Scandal hunting}

Scandal hunting has become the default position across the UK national press, and any number of online news and social media sites. It is a cost-effective business model which requires up-front investment, but holds the potential to deliver enormous returns (Economist, $7^{\text {th }}$ July 2011). Scandal hunting can involve: sting operations in which public figures are 'caught' engaging in scandalous behaviours by journalists in disguise; teams of journalists proactively seeking evidence to verify rumours and allegations that might in turn result in a new scandal scoop; or an open invitation - now a standard addition to many news sites - for consumers to share scandalous news. Journalists are prone at times to move as a noisy pack, acting in a manner that Tiffen (1999) describes as picking off small prey and resembling scavengers more than hunters. Heightened competition and uncertainty in the intermediatised news market is driving news agencies toward the proactive hunt for scandal. Today that hunt is relentless, and corporate news media antennae are constantly tuned-in to any possibility of a fresh scandal story. What is striking about scandal hunting is that all UK news agencies appear to be actively engaged in it, from the Daily Telegraph's award-winning breaking of the politicians' expenses scandal in 2011, to the phone-hacking scandal reported by all UK newspapers that led directly to the closure of the 168-year-old News of the World in 2011, to the Guardian's Pulitzer Prize winning public service journalism for their articles about mass surveillance based on the leaks by Edward Snowden in 2013, and the Panama Papers data leak of 2016 exposing the offshore tax avoidance activities of the rich and powerful. The 2014 UK Press Awards were replete with winners across the spectrum of newspapers for scandal reporting in one form or another (http://www.pressawards.org.uk/page-view.php?pagename=Winners-2014, accessed $17^{\text {th }}$ March 2016). While scandals may be activated and subsequently 'owned' by particular news agencies - usually newspapers - scandals are intermediatised both across 
and within national news outlets, and may be inflected differently depending on that outlet's ideological agenda. In addition to being commercially beneficial, scandal hunting is also inherently political. The overriding objective is to identify 'latent' scandals that might be 'activated' through media exposure and developed through successive phases of our process model of scandal - reaction, amplification, and accountability.

\section{Latency}

In the latent phase, potentially scandalous transgressions are known to or suspected by others and may be 'open secrets' within the institution, but they remain concealed from the wider world. Institutions can mobilise considerable resources and engage in various forms of denial, dismissal, diversion to displacement to neutralise the risks of the 'uncomfortable knowledge' becoming public (Cohen, 2001; Marris et al., 2014). These techniques of denial and neutralisation help explain why most scandals never break. Witnesses at all levels of an institutional hierarchy can remain in denial. Even when victims and whistle-blowers ${ }^{1}$ come forwards and make internal complaints or threaten to go public, alleged transgressors may deny all charges and senior managers may place the reputation of the institution above the rights of clients and employees and engage in dismissal or cover-up. Irrespective of an institution's internal turbulence, so long as the transgressions are not made public, the scandal will remain latent. We would propose that the corporate news media shift to scandal hunting as a primary business model and the social media transformation of scandals into viral phenomena means that an increasing number that might previously have remained latent are today being activated.

\section{Activation}

\footnotetext{
${ }^{1}$ In a context of intermediatised scandal-hunting, all citizen-consumers are viewed as potential whistleblowers and are actively encouraged by corporate news media to disclose scandalous allegations. The UK government has introduced new laws designed to protect whistleblowers against institutional retribution for disclosing 'wrongdoing' at work (https://www.gov.uk/whistleblowing/what-is-a-whistleblower). Despite legal protection, the whistleblower's status is without guarantee. Across jurisdictions, their usefulness as a source of scandal activation will be determined by news media on a case-by-case basis. Any questions regarding their credibility may result in whistleblowers themselves becoming targets for trial by media.
} 
In the networked society communication technologies are ubiquitous and information is abundant. Scandalous allegations against individuals and institutions may be circulated instantly and globally across any number of social media. But social media exposure alone is seldom sufficient to trigger a scandal's transition from the 'latent' to 'activated' phase. Scandalous allegations circulating on social media - however credible they may seem and however visible and widely consumed by networks of diverse publics - still only gain mainstream authority and validation once appropriated and recirculated by corporate news media (Chagnon \& Chesney-Lind, 2015; Liebes \& Blum-Kulka, 2004). Even then, the news media must be prepared not only to print or broadcast the alleged transgressions, but also to declare publicly that they know the transgressor's identity and are prepared to reveal it. ${ }^{2}$ Because of initial uncertainty about an allegation's authenticity and source trustworthiness, and the risk of defamation or libel action, the decision by a news agency to give credibility to scandalous allegations is critical (Basinger \& Rottinghaus, 2012). Editors must be satisfied that there is sufficient evidence to substantiate the allegations, that the alleged transgressions are relevant to the individual's or institution's public duties, and that consumers will care (Sabato et al., 2000). Doubts around any of these criteria may discourage news agencies from reporting allegations, even if they know them to be true. Thus even in a viral context of scandal hunting, scandal activation is not inevitable. It requires the interaction of the diverse sets of participants in the scandal process - victims and whistle-blowers, pressure groups and moral entrepreneurs, journalists and news agencies, the publics that consume the 'news', and of course those who stand accused of the alleged transgressions. Each of these participants acts on the basis of their interpretation of the situation at their particular point in the network, and each dependent on their power - has a more or less active part to play in a scandal's activation and development. Scandalous allegations circulating online may or may not provoke a reaction from the accused. Allegations that corporate news agencies are prepared to endorse through publication - turning them into 'official' knowledge and giving the impression that they have been crosschecked and corroborated - are more difficult to ignore. Once printed or broadcast in the corporate media, the 'validated' and mainstreamed

\footnotetext{
${ }^{2}$ It may not be in the best interests of the news agency to reveal an alleged transgressor's identity immediately.
} 
scandalous allegations will inevitably spread to, or return to, social media, and circulate in a manner that is impossible to control.

\section{Reaction}

Scandal activation is intended to provoke shock, outrage and fascination from consumers, and a range of possible reactions from the accused, including confession and apology; excuse; justification; and defiance or denial (Schönbach, 2010). The typical institutional reaction is to prioritise the protection of its reputation against negative publicity (Gardner, 2012). The techniques of denial and neutralisation used in the latent phase to prevent scandal activation may now be deployed in an attempt to close down the scandal and minimise reputational damage (Cohen, 2001; Katz, 1979; Marris et al., 2014; Rayner, 2012; Zerubavel, 2006). However, since public naming requires editorial assurance that the available evidence substantiates the allegations, the default news media position at the point of scandal activation is that the accused is guilty. Denial, therefore, is interpreted as public lying. Those accused of lying about or covering-up their alleged transgressions will be plunged into trial by media, in which claim and counter-claim are publicly scrutinised for validity, and which can fuel the scandal though the next phases of its development.

Trial by media (TBM) is a key driver of institutional scandals. As we have established elsewhere (Greer \& Mclaughlin, 2011, 2012a, 2013, forthcoming), TBM is a market-driven form of populist justice in which individuals and institutions are accused, prosecuted, judged, sentenced and permanently stigmatised in the 'court of public opinion'. The nature and target of such trials are diverse - from identifying and hounding public figures and institutions perceived to think they are above the law or deemed to have offended against an assumed moral consensus, to pre-judging the outcome of investigations involving 'unknowns', to 'retrying' those considered to have evaded formal legal justice, to condemning whole institutions or the state itself for failing to deliver on obligations and responsibilities. The scandalous charges that drive TBM range across the categories of corruption, immorality and incompetence.

British newspapers have always cast themselves as barometers of the public temper, arbiters of the public interest and guardians of public morality. By encouraging news 
consumers to engage in immediate 'red button' judgement, TBM reclaims aspects of 'justice' from the courts and returns them to a networked citizenry. The extra-legal news media investigation of suspected crimes and criminals can lead to legal prosecutions that otherwise would not have occurred, and in that sense trial by media has clear potential to deliver justice by activating due process. But TBM also challenges and subverts it. In a direct inversion of due process, TBM cases are premised on a presumption of guilt. This presumption of guilt, in turn, precipitates a relentless search for other forms of incriminating 'evidence' that serve to flesh out the image of the accused as 'guilty' - of this transgression, of this transgression and others, if not of this transgression then of something equally bad on another occasion. ${ }^{3}$ While both criminal and civil legal cases tend to regard (with some exceptions) opinion and hearsay evidence as inadmissible, 'evidence' in TBM varies dramatically from that which might be legally admissible to conjecture and insinuation. Newspaper editors and lawyers must only be persuaded that the available evidence - whatever it is - is sufficiently robust (or newsworthy) to justify the risk of libel action, irrespective of whether or not that evidence would stand up in a court of law. Those who maintain their innocence, exercise their right to reply or seek legal remedy risk escalating scrutiny aimed at uncovering further evidence to persuade news consumers of their guilt. Each stage of TBM is intensified through the involvement of social media. In the process of intermediatisation we witness a shredding of the distinction between public and private information. The outcomes of TBM may vary from a chilling of public sentiments towards the 'accused' (whether individual or institutional), through permanent stigmatisation, to criminal prosecution, to the introduction of new regulatory frameworks, to changing institutional practice and wider policy reform.

TBM uses the naming and disintegrative shaming of individual and institutional 'wrongdoers' to dramatise and clarify moral boundaries (Braithwaite, 1989; Cavender et al., 2010), in many cases conjuring in nostalgically reactionary manner a fictional, morally cohesive past. In this sense, TBM can be and often is conservative. Yet TBM is not always driven by the desire to maintain the status quo and protect establishment interests. On the contrary, it is establishment elites representing the full political spectrum who increasingly

\footnotetext{
${ }^{3}$ There is an extensive literature on the subversion of due process, not least miscarriages of justice, from within the criminal jutice system (Huff \& Killias, 2008; Woffinden, 1987). Our comparison here is with how due process is supposed to work.
} 
find themselves in the firing line. TBM is politically and normatively complex, and grasping this complexity is key to understanding its defining role within contemporary institutional scandals.

\section{Amplification}

For scandal amplification to occur the actions of individual transgressors need to be connected with wider institutional structures and practices. As noted above, US executive scandals tend to be reported in the news media and understood more widely as exceptional and individualised disruptions to the smooth running of a system deemed otherwise broadly sound. Our research on UK institutional scandals indicates that scandal amplification shifts the focus of attention from the individual and exceptional to the institutional and systemic. A scandal can amplify for a variety of reasons. The investigation of an individual alleged transgressor may implicate others within the same institution to the extent that the scandalous behaviour can be described as normalised and the institution itself systemically corrupt, immoral or incompetent. It may become apparent that the institution knew about the alleged scandalous behaviour, whether perpetrated by one individual or many, failed to prevent it, somehow facilitated it, or actively covered it up. Evidence may come to light that the alleged transgressions took place across multiple institutions, indicating a network of scandalous activities that required some form of institutional coordination or complicity. Whatever the mechanism, as a scandal amplifies from the individual to the institutional level, the order of seriousness increases. If a scandal is contained at the individual level the preferred outcome for institutions seeking to limit reputational damage - the institution can deal publicly and robustly with the transgressor and emerge re-legitimated from the ordeal, having visibly purged itself of the bad apple. While individualised scandals may be resolved with individualised solutions, institutionalised scandals require institutional reform - of policy, practice, training, or structures of accountability. Such reform, implying the whole barrel may be rotten, can be costly, time-consuming and highly damaging to the institution's reputation. In a mixed economy of inter-agency service provision, an amplifying scandal can quickly consume multiple institutions. 


\section{Accountability}

If a scandal is successfully contained at the individual level the accountability phase involves the separation of individual and institutional accountability. The focus remains fixed on the alleged transgressor, who may be subjected to trial by media, institutional discipline, and/or legal prosecution. The institution itself remains the backdrop rather than the main focus of attention. Faced with mounting media pressure and intensified investigation, and isolated from her/his institutional employer, the alleged transgressor may choose to tender a public confession and apologise, or continue to protest her/his innocence. As many public figures have learned to their cost, continued denial (even if ultimately found not guilty in court) can be costly, merely prolonging trial by media as the legal case continues.

Should institutional attempts at containment fail, the accountability phase of an amplifying scandal involves the conjoining of individual and institutional accountability and asks who else is guilty? Individual 'guilt' generally relates to involvement in the transgressive act behind the unfolding scandal. The more senior the transgressor, the more serious the scandal. As a scandal amplifies through the institutional hierarchy, the notion of 'guilt' amplifies with it. Blame can be attributed not only to the alleged perpetrators, but also to the senior managers responsible for the institutional structures, practices and wider culture that failed to prevent, facilitated, or sought to cover-up the scandalous behaviour when it became known. As more individuals are implicated in the interlocking and mutually reinforcing elements of an amplifying scandal, intermediatised outcry and calls for justice grow louder. Truth-seeking investigations simultaneously fuel scandal hunting and amplification by attempting to unearth evidence to corroborate the initial allegations and digging deeper into a widening range of individual and institutional practices with a view to discovering new or supplementary accusations, accusers and targets for trial by media. The reputation of entire institutions can be destroyed by scandal. Yet for justice to be seen to be done, particularly in a context of TBM-driven scandal amplification, individuals must be held to account. In this conjoining of individual and institutional accountability, it is the most senior figures who become the focus as news media go in for the kill.

Not all individuals or institutions accused of scandalous transgressions and targeted by trial by media are prosecuted, still less found guilty, in a court of law. In the face of high-profile no further action or not guilty verdicts, the interpretive processes shaping the scandal's 
news media construction are adapted accordingly. Whistle-blowers and alleged victims increasingly encouraged by the authorities to come forwards and report their victimisation are recast by sceptics as opportunists, liars and fantasists. The authorities, in turn, tasked with establishing the 'official truth' and delivering justice for victims and society, may themselves be implicated in the ongoing process of scandal amplification, accountability and hunting. The justice system is ridiculed for wasting tax payers money by bringing the cases to court. The professional and private lives of the alleged transgressors, now formally acquitted, may already be irreversibly stigmatised by TBM, and they may still find themselves judged guilty in the court of public opinion. In such cases, only the news media benefit, since whatever the outcome of the accountability phase the scandal story continues to sell.

We now turn our attention to the wider significance and impact of public sector institutional scandal. What follows is exploratory and in places speculative, but we feel it is important to engage with the broader picture in order to suggest directions for theory-building and further empirical research.

\section{Managing the Institutional Scandal Machine}

We have argued that scandal has been elevated to a premium genre across news markets and that scandal hunting is now a business model. Corporate and social media are thriving on the proliferation of UK public sector scandals by cumulatively and relentlessly portraying a permanent crisis in governance brought about by the failure of core public institutions in which corruption, incompetence or immorality are systemic. Responsibility for the effective administration of these institutions, and therefore accountability for their failure, has traditionally rested with the state. The news media reporting of scandal as institutionalised and systemic thus implicates the state, as the responsible authority, as a key part of the problem. The state, in turn, is forced to act.

There is an ongoing debate about what we would define as the de-institutionalisation of the state and its consequences for public services in Britain. What Rhodes $(1994,1997)$ terms the 'hollowing out' of the state embodies four interrelated trends: privatisation and limiting public intervention; contracting-out central and local government services to external 
agencies; loss of functions by national governments to transnational governance; and limiting public servants' discretion through managerial accountability and enhanced political control. Two key consequences of these trends are the fragmentation and diminished accountability of the state. Rhodes (1994: 149) further proposed that the combination of fragmentation and diminished accountability would erode the state's governmental capacity to steer and heighten the risks of catastrophic service failures. Responding to critics who argue that recent trends have in fact bolstered the state's core political and administrative control mechanisms, in more indirect but nonetheless more penetrating and effective ways (Holliday, 2000; Marinetto, 2003), Rhodes (2007) accepts that the core executive can act decisively through coordination and control in certain circumstances. He maintains, however, that the task of central steering has become more complex and reliant on powerdependent relations with other actors and organisations, and that too little attention has been paid to the 'sour laws of unintended consequences' (Rhodes, 2007: 1255). Paramount among these unintended consequences, we would argue, are the heightened risks of scandals presented by the hollowed out state's residual public institutions which, as Strange (1996) has noted, are seemingly blighted by service delivery failure in the face of rising citizen-consumer expectations. These risks and failures must still be managed, and so the state is forced to act. Consistent with our interactionist approach, we view this action not as 'a mere release of activity brought about by the play of initiating factors' (Blumer, 1986: 54). Rather, the state finds itself confronted with a situation in which it must engage and cope with scandal proliferation across its residual institutions, interpret and analyse it, and construct a line of action to manage it.

Power (2004: 12-13) places risk management at the heart of neoliberal governance, arguing that it has become a mode of organisation in its own right:

This phenomenal expansion of the risk industry reflects a number of different but contingent pressures for change in organisational practices for dealing with uncertainty. There has been a fusion of ideas about organisational governance and corporate responsibility... New models of regulation are in vogue. Scandals and crises of the past ten years have been catalysts for the emergence of a conception of risk management with wide scope, unifying traditionally separate areas, such as health 
and safety, insurance and project management under a single model but also absorbing new objects of concern.

The logics of risk management are also central to regulatory state theory, which is concerned specifically to understand the emergence of new models of regulation (Braithwaite, 2000; Burgess, 2011; King, 2007; Moran, 2003; Veggeland, 2009). By connecting these insights, we can begin building a theoretical framework that can make sense of the lines of action constructed by the regulatory state to govern the risks presented by scandal within its failing public institutions. Regulatory state scholars have proposed that we are witnessing an emergent state form that has displaced Keynsian social security models of governance. The regulatory state is 'premised upon a neo-liberal combination of market competition, privatized institutions, and decentred, at-a-distance forms of state regulation' (Braithwaite, 2000: 222). In the shift to a regulatory mode of governance, the state has reorganised its governmental structures and recalibrated the strategies and methods used to deliver public goods and services. Moran (2003) agrees with Rhodes that the process of hollowing out has diminished the state's policy competence, symbolic capital and sovereignty to the point that its governmental capacity has been reduced to 'regulation'. Today the British state is constituted through a complex, decentred regulatory regime of quasi-autonomous agencies. It is responsible for implementing the rules, standards and regulations that govern the relationships between citizen-consumers and the 'market' in which they receive contractualised, publicly funded goods and services, but is primarily responsible neither for the maintenance of those relationships nor for the delivery failures of the institutional service providers. ${ }^{4}$

The implications of the decline of citizens' trust in and deference toward institutional authority have been widely discussed (Fukuyama, 2006; Seldon, 2009; Young, 2007). Less has been written about the state's collapse of trust in and deference toward its own historic institutional arrangements. The legitimacy and authority of the $21^{\text {st }}$ century regulatory state is no longer inextricably linked to the reputation of its core public institutions. Rather, it derives from a commitment to enhancing institutional accountability through transparency,

\footnotetext{
${ }^{4}$ The responsibilised citizen-consumer (Clarke et al., 2007) - now empowered to choose within a free marketplace of public goods and services - may be more inclined to complain when publicly funded institutions fail to deliver adequate services.
} 
openness, scrutiny, audit, review and performance management (House of Lords Select Committee on the Constitution, 2005). Faced with a succession of interconnected and amplifying scandals across the BBC, the police, the National Health Service, the Crown Prosecution Service, and the education sector, among others, public institutions become risks to be offset and liabilities to be regulated and reformed, rather than assets to be supported and protected. And yet, the 'risk management of everything' itself produces new risks, including Rhodes' 'sour laws of unintended consequences'.

\section{Institutional Scandal and Public Inquiry}

The relentlessly adversarial news media are attuned to the regulatory state's logics of deinstitutionalisation and risk management, and will not hesitate to challenge its commitment to transparency, scrutiny, audit and review. In an attempt to re-appropriate control of the news agenda and reposition itself as part of the solution rather than part of the problem the state must attempt manage the scandal machine. The key mechanism used in pursuit of this objective is the public inquiry:

The term 'public inquiry' has a very broad meaning, and the history of the British government shows that there are in fact a number of forms of 'inquiry' available, designed, in principle to fulfil specific functions. Sometimes the wish may be simply to establish the relevant facts, leaving their interpretation, the allocation of 'blame' and recommendations for the future to other agencies such as Ministers, Parliament or the courts. In other circumstances it may be thought desirable that the 'inquiry' itself undertake these broader, perhaps more delicate tasks. A prime purpose of some inquiries may also be to allay public (and Parliamentary) disquiet about some public issue or a 'scandal' (House of Commons Library, 2004).

In the UK, public inquiries can be authorised by institutions or on a statutory basis by the state (Beer et al., 2011). Burgess (2011) has analysed the increase in public inquiries from the 1950s to the early-2000s, and notes that it cannot be understood simply in terms of an increase in sufficiently serious incidents, but must be situated within the wider political context that shapes decision making. That said, the suggestion that inquiries are 'casually instigated in response to every demand' is equally unrealistic, since it 'rejects any notion of 
political choice and agency... They remain an instrument of last resort, particularly when they concern events that occur under the incumbent administration' (Burgess, 2011: 10, 11). With respect to the proliferation of UK public sectors scandals, the regulatory state's increased inclination to accommodate the demands of news media-driven campaigns for public inquiries indicates that they are no longer an instrument of last resort. Rather, we would propose that it can be understood as a line of action constructed to regulate public sector scandals through the reconfiguration of three key dynamics - responsibility, accountability and time.

Establishing a public inquiry contributes to redefining state responsibility from ensuring the effective administration of its core institutions in order to improve the quality of public services, to initiating an investigative process when those institutions fail and people are harmed. Public sector scandals become crises first to be addressed within the managerial hierarchy of the institution in question. The regulatory state intervenes only when that institution's internal procedures have demonstrably failed to deliver accountability in a manner satisfactory to the news media.

Establishing a public inquiry redefines accountability by repositioning the regulatory state as part of the solution rather than part of the problem. As Rhodes (1994) predicted, the hollowing out of the state creates layers of institutional complexity that obscure notions of who is accountable to whom and for what. In a context of contracting-out, operational management is detached from state accountability (House of Lords Select Committee on the Constitution, 2005; Jordan, 1992, cited in Rhodes, 1994). Furthermore, as Burgess (2011) has pointed out, inquiries operating in a culture of risk management are predisposed to understand individual incidents as a consequence of deficient institutional arrangements, and to demonstrate independence by demanding wholesale reform of those arrangements. The state can use these blurred lines of accountability and embedded risk-based assumptions to deflect culpability for public sector scandals away from itself and more fully onto the institutions in question. Indeed, the state's involvement in public sector scandals today signals that the scandalised institution will be held to account for a double-failure the normative failure to deliver on its public service responsibilities, and procedural failure to self-regulate and control its own practices. 
Establishing a public inquiry facilitates temporal regulation of scandals. It conveys a sense of decisive action in a classic example of impression management, whilst at the same time extending the operational timeframe. High cost, procedurally and legally complex, multifacetted inquiries may take years to undertake and run across successive elections cycles. By the time an inquiry finally reports, one government may have been replaced by another. Even if the same government is still in power, it will have had ample time to consider possible outcomes and prepare a series of carefully timed responses to further mitigate its own responsibility and accountability. The scandal may be relegated to a ministerial footnote rather than an administration-defining heading. For cynics, establishing public inquiries in the wake of institutional scandals constitutes little more than a delay tactic as part of a longer-term state strategy of bureaucratising conflict (Blom-Cooper, 1996; Elliott \& McGuinness, 2002; Gilligan \& Pratt, 2013; Keller, 2014; Sedley, 1989). Should the inquiry as is likely - connect individual scandalous transgressions with systemic institutional failings, the state will be able to claim strong justification for continued radical public sector reform in line with the twin-track regulatory strategies of managerialism on the one hand, and market competition and privatisation on the other.

We would suggest, therefore, that regulatory state's changing reaction - from a commitment to protect the reputation of its public institutions, to an unsentimental antistatism position of distancing itself from those institutions and, by establishing public inquiries, ceding to external authorities power in the pursuit of 'truth' and 'accountability' is driven by two interrelated objectives. In the shorter term, the objective is to avoid reputational damage through scandal by association - the risk that the current succession of public sector scandals will diminish the state's perceived honesty and competence. In the longer term, the objective is the ongoing reconfiguration of the state's relations with its residual public institutions. Thus the regulatory state increasingly rejects denial and neutralisation as the default responses to scandalous allegations of incompetence, immorality or corruption within public institutions. Instead of placing above all else their reputational protection, it readily concedes that the alleged transgressions may have taken place, but must be fully investigated before culpability can be established and any guilty parties held to account. It then acts - publicly and decisively - to begin that investigative process. 
Yet establishing a public inquiry is inherently risky and can create as many problems as it has potential to resolve. Public inquiries, in their classic state-authorised form, were part of the state's defensive structure - self-legitimating, operating with chairs who were pillars of the establishment and utilising bureau-legal procedures that were exclusionary in nature (BlomCooper, 1996). The chairs and members did not need to be told that their primary role was to safeguard state institutions by neutralising scandals. Deliberations and conclusions were shaped by the following neutralising procedures:

(a) narrowing the focus of attention ('sticking to the immediate facts')

(b) historicising the scandals ('that was then')

(c) exceptionalising the wrong-doing ('need for a sense of perspective')

(d) acknowledging faults ('mistakes had been made')

(e) dispersing responsibility ('multiple versions of events')

(f) apportioning low-level individual blame ('rotten apples')

(g) avoiding a repeat scandal ('lessons to be learned')

In the context of a prevailing culture of deference, the welfare state could depend on the chair's public standing and political neutrality to counter any accusations that public inquiries were cover-ups and/or whitewashes. In a fundamental shift, public inquiries established by the regulatory state are immediately subjected to intense and adversarial public examination. The chair's credibility, the appointment process itself, and the suitability of inquiry members will be scrutinised and tested across news and social media forums, and trial by media of anyone deemed unacceptable or inappropriate is an ever-present risk. The first two Chairs of the Independent Inquiry into Child Sexual Abuse (IICSA), Baroness Elizabeth Butler-Sloss and Fiona Woolf, were subjected to gruelling trial by media. Both resigned.

The functioning and aims of the contemporary public inquiry have also changed. In the evolving regulatory context, public inquiries are more reflexive and transparent in their workings and methods, holding open hearings and maintaining interactive websites. Navigating through the contemporary scandal minefield obliges inquiries to demonstrate 
their independence, impartiality, thoroughness and accountability by publishing evidence for public scrutiny as they proceed. They are more explicitly victim-centred, incorporating victim input into their terms of reference and ensuring victim participation throughout proceedings. There is also greater willingness to acknowledge the conflicting pressures and expectations that surround public inquiries. Lord Laming, who chaired the Victoria Climbié Inquiry, summarises the new sensibilities, stating that inquiries must: 'provide an assurance that the facts surrounding an alleged failure will be subjected to objective scrutiny. They are expected to reach judgements on why terrible events happened. They often make recommendations on how such events might be prevented in future. They may give relief to some and allow the expression of anger and outrage to others. They are often disturbing and painful events' (House of Commons Public Administration Select Committee, 2005: 9).

As we have seen with the Independent Inquiry into Child Sexual Abuse, public inquiries have also been transformed in terms of their historical remit, investigative powers, resources, technological capabilities and relationships with the criminal justice process. They have the capacity to dissect institutional scandals in ways that were not possible in the past and, through their communication strategies, can impact directly on public understanding of the institutional scandal. However, the failure of a public inquiry to fulfil any of its stated commitments or meet the expectations of stakeholders and citizen-consumers will intensify the institutional crisis and fuel the scandal machine, with demands for an inquiry into the botched inquiry. Under such risky circumstances, the public inquiry becomes the official epicentre of the institutional scandal.

\section{Conclusions}

Scandals will always have an infotainment edge, but that does not make them trivial. By triggering public inquiries that might take years to complete, and naming multiple alleged offenders in the process, institutional scandal is transforming how justice is administered in the UK. In the first part of this article we developed a process model of institutional scandal. In the second part, we examined the reaction of the regulatory state to public sector scandal proliferation. Our aim has been to analyse the transforming nature, significance and impact of institutional scandals and the forms of regulatory governance to which they are 
giving rise. We have identified scandal hunting as a business model for both corporate news media and social media, and highlighted the interaction between phases of individual scandals, and between scandals over time. Institutional scandals are best conceptualised as mutually reinforcing within an intermediatised news market where the boundaries between 'old' and 'new' media have become irrelevant and institutional failure has become the defining explanatory trope. Our conceptualisation seeks to better capture the viral processes through which scandals activate and amplify within and between institutions and individuals, and their temporally unconstrained and ungovernable nature.

In the UK, as a result of the continuing amplification of the Sir Jimmy Savile scandal (Greer \& McLaughlin, 2013), the floodgates have opened and scandal consciousness has intensified to unprecedented levels. Categories of behaviour deemed potentially scandalous have widened and every public institution runs the risk of reputation-shredding accusations. The ubiquity of scandal stories means that news agencies can choose which scandals to investigate in line with their own ideological agendas. While citizens have traditionally been attracted as news consumers, they are now recruited as active participants in the process of scandal hunting, activation and amplification. In this sense, corporate news media and social media can become alternative platforms for delivering 'justice' to victims who for decades may have been denied legal recourse by institutional and state cover-up. The regulatory state, in its turn, is adapting its response to public sector scandal, and appears increasingly inclined to establish public inquiries. Scandalised public institutions are no longer invulnerable. They are being cut adrift from automatic state protection and left to account for themselves with potentially catastrophic consequences. Inquiries into the failures of public institutions generate recommendations that in turn are being politicised to fuel further radical public sector reform. In redirecting its responsibility and accountability in the face of public sector scandal proliferation, the regulatory state is simultaneously seeking to distance itself from its residual public institutions, whilst extending its control over them.

We have argued, however, that the contradictory logics driving the regulatory state's attempts to manage the scandal machine risk unintended consequences, not least because of the transformed public inquiry. Unlike its welfare state predecessor, today's public inquiry is immediately interpellated into the scandal machine. Its members, processes, practices and findings may be subjected to trial by media just as much as those implicated in 
the scandal it has been established to regulate. Scandals are challenging the defining qualities of competence and honesty that determine the trustworthiness and legitimacy of public sector institutions and the individuals that work in them. Their impact extends beyond justifying the continued hollowing out of the regulatory state. Institutional scandals are hollowing out the cherished history and memories of the post-War welfare consensus. Testing our process model of institutional scandal with comparative empirical data on both public and private institutions, and crucially on scandals that did not activate as well as those that did, will lead to a deeper understanding of the global rise of scandal consciousness and the significance and impact of institutional scandal across different media environments and state formations.

\section{References}

Ashton, P., \& Christophers, B. (2015). On arbitration, arbitrage and arbitrariness in financial markets and their governance: unpacking LIBOR and the LIBOR scandal. Economy and Society, 44(2), 188-217. doi: 10.1080/03085147.2015.1013352

Basinger, S., \& Rottinghaus, B. (2012). Skeletons in the White House Closets: An Empirical Investigation into Modern Presidential Scandals. Political Science Quarterly, 127(2), 213-239.

Beer, J., Dingemans, J., \& Lissack, R. (Eds.). (2011). Public Inquiries. Oxford: Oxford University Press.

Blom-Cooper, L. (1996). Some reflections on public inquiries. In J. Peay (Ed.), Inquiries after Homicide. London Duckworth.

Blumer, H. (1986). Symbolic interactionism; perspective and method. Berkeley and Los Angeles: University of California Press.

Braithwaite, J. (1989). Crime, shame, and reintegration. Cambridge Cambridgeshire ; New York: Cambridge University Press.

Braithwaite, J. (2000). The New Regulatory State and the Transformation of Criminology. British Journal of Criminology, 40(2), 222-238. doi: 10.1093/bjc/40.2.222

Burgess, A. (2011). The changing character of public inquiries in the (risk) regulatory state. British Politics, 6(1), 3-29.

Butler, I., \& Drakeford, M. (2005). Scandal, social policy and social welfare (2nd ed.). Bristol: Policy. Castells, M. (2009). Communication power. Oxford: Oxford University Press.

Cavender, G., Gray, K., \& Miller, K. W. (2010). Enron's perp walk: Status degradation ceremonies as narrative. Crime, Media, Culture, 6(3), 251-266. doi: 10.1177/1741659010382329

Chagnon, N., \& Chesney-Lind, M. (2015). "Someone's been in the house:" A tale of burglary and trial by media. Crime, Media, Culture, 11(1), 41-60. doi: 10.1177/1741659014566825

Clarke, J., Newman, J., Smith, N., Vidler, E., \& Westmarland, L. (2007). Creating citizen-consumers : changing publics \& changing public services. London ; Thousand Oaks, Calif.: SAGE.

Cohen, S. (2001). States of denial : knowing about atrocities and suffering. Cambridge: Polity.

Dagnes, A. (2011). Sex scandals in American politics : a multidisciplinary approach to the construction and aftermath of contemporary political sex scandals. New York: Continuum International Pub. Group.

Davis, L. J. (2006). Scandal : how "gotcha" politics is destroying America (1st ed.). New York: Palgrave Macmillan. 
Elliott, D., \& McGuinness, M. (2002). Public Inquiry: Panacea or Placebo? Journal of Contingencies and Crisis Management, 10(1), 14-25. doi: 10.1111/1468-5973.00177

Entman, R. M. (2012). Scandal and silence : media responses to presidential misconduct. Cambridge ; Malden, MA: Polity.

Fukuyama, F. (2006). The end of history and the last man (1st Free Press trade pbk. ed.). New York: Free Press ;.

Gardner, F. (2012). Defensive Processes and Deception: An Analysis of the Response of the Institutional Church to Disclosures of Child Sexual Abuse. British Journal of Psychotherapy, 28(1), 98-109. doi: 10.1111/j.1752-0118.2011.01255.x

Garment, S. (1991). Scandal : the crisis of mistrust in American politics (1st ed.). New York: Times Books.

Gilligan, G., \& Pratt, J. (Eds.). (2013). Crime, Truth and Justice: Official Inquiry, Discourse, Knowledge. Cullompton: Willan.

Ginsberg, B., \& Shefter, M. (1999). Politics by other means : politicians, prosecutors, and the press from Watergate to Whitewater (Rev. and updated ed.). New York: W. W. Norton.

Greer, C., \& Mclaughlin, E. (2011). Trial by media: Policing, the News 24-7 News Mediasphere, and the Politics of Outrage. Theoretical Criminology, 15(1), 23-46.

Greer, C., \& McLaughlin, E. (2012a). Media Justice: Madeleine McCann, Intermediatization and 'Trial by Media' in the British press. Theoretical Criminology, 16(4), 395-416. doi: $10.1177 / 1362480612454559$

Greer, C., \& McLaughlin, E. (2012b). 'This is not Justice': Ian Tomlinson, Institutional Failure and the Press Politics of Outrage. British Journal of Criminology, 52(2), 274-293. doi: $10.1093 /$ bjc/azr086

Greer, C., \& McLaughlin, E. (2013). The Sir Jimmy Savile scandal: Child sexual abuse and institutional denial at the BBC. Crime, Media, Culture, 9(3), 243-263. doi: 10.1177/1741659013513782

Greer, C., \& Mclaughlin, E. (2015). The Return of the Repressed: Secrets, Lies, Denial and 'Historical' Institutional Child Sexual Abuse Scandals. In D. Whyte (Ed.), How Corrupt is Britain? London: Pluto.

Greer, C., \& McLaughlin, E. (forthcoming). Trial by Media. In A. Liebling, S. Maruna, \& L. McAra (Eds.), The Oxford Handbook of Criminology (6th ed.). Oxford: Oxford University Press.

Hallahan, K. (1999). Seven models of framing: Implications for public relations. Journal of Public Relations Research, 11(3), 205-242.

Holliday, I. (2000). Is the British State Hollowing Out? The Political Quarterly, 71(2), 167-176. doi: 10.1111/1467-923X.00291

House of Commons Library. (2004). Investigatory inquiries, Standard Note: SN/PC/2599.

House of Commons Public Administration Select Committee. (2005). Government by Inquiry. (HC 51I, Incorporating HC 606, Session 2003-04).

House of Lords Select Committee on the Constitution. (2005). The Regulatory State: Ensuring its Accountability. (HL Paper 68-I).

Huff, C. R., \& Killias, M. (2008). Wrongful conviction international perspectives on miscarriages of justice (pp. viii, 318 p.). Retrieved from http://www.columbia.edu/cgibin/cul/resolve?clio7451945

Katz, J. (1979). Concerted Ignorance - The Social Construction of Cover-Up. Urban Life, 8(3), 295-316.

Keeble, R., \& Mair, J. (Eds.). (2012). The Phone Hacking Scandal: Journalism on Trial. Suffolk: Abramis.

Keller, M. R. (2014). When is the State's Gaze Focused? British Royal Commissions and the Bureaucratization of Conflict. Journal of Historical Sociology, 27(2), 204-235.

King, R. (2007). The regulatory state in an age of governance : soft words and big sticks. Basingstoke, Hampshire; New York: Palgrave Macmillan.

Liebes, T., \& Blum-Kulka, S. (2004). It takes two to blow a whistle: do journalists control the outbreak of scandal? American Behavioural Scientist, 47(9), 1153-1170. 
Lull, J., \& Hinerman, S. (1997). Media scandals : morality and desire in the popular culture marketplace. Oxford: Polity.

Marinetto, M. (2003). Governing beyond the Centre: A Critique of the Anglo-Governance School. Political Studies, 51(3), 592-608. doi: 10.1111/1467-9248.00443

Markovits, A. S., \& Silverstein, M. (1988). The Politics of scandal : power and processes in liberal democracies. New York: Holmes \& Meier.

Marris, C., Jefferson, C., \& Lentzos, F. (2014). Negotiating the dynamics of uncomfortable knowledge: The case of dual use and synthetic biology. BioSocieties, 9(4), 393-420.

Moore, C. (1995). Betrayal of Trust: The Father Brendan Smyth Affair and the Catholic Church. Dublin: Marino.

Moran, M. (2003). The British Regulatory State: High Modernism and Hyper-Innovation. Oxford: Oxford University Press.

Pattie, C., \& Johnston, R. (2012). The Electoral Impact of the UK 2009 MPs' Expenses Scandal. Political Studies, 60(4), 730-750. doi: 10.1111/j.1467-9248.2011.00943.x

Petersen, A. H. (2012). Scandals of classic Hollywood: sex, deviance, and drama from the golden age of American cinema.

Power, M. (2004). The Risk Management of Everything: Rethinking the politics of uncertainty. London: Demos.

Pratt, J. (2008). When Penal Populism Stops: Legitimacy, Scandal and the Power to Punish in New Zealand. Australian \& New Zealand Journal of Criminology, 41(3), 364-383. doi: 10.1375/acri.41.3.364

Rayner, S. (2012). Uncomfortable knowledge: the social construction of ignorance in science and environmental policy discourses. Economy and Society, 41(1), 107-125. doi: 10.1080/03085147.2011.637335

Rhodes, R. A. W. (1994). The Hollowing Out of the State: The Changing Nature of Public Service in Britain. The Political Quarterly, 65(2), 138-151. doi: 10.1111/j.1467-923X.1994.tb00441.x

Rhodes, R. A. W. (1997). Understanding governance : policy networks, governance, reflexivity and accountability. Bristol, Pa. ; Buckingham, Great Britain: Open University Press.

Rhodes, R. A. W. (2007). Understanding Governance: Ten Years On. Organization Studies, 28(8), 1243-1264. doi: 10.1177/0170840607076586

Rottinghaus, B. (2015). The Institutional Effects of Executive Scandal. New York: Cambridge University Press.

Rozell, M. J., \& Wilcox, C. (2000). The Clinton scandal and the future of American government. Washington, D.C.: Georgetown University Press.

Sabato, L., Stencel, M., \& Lichter, S. R. (2000). Peepshow : media and politics in an age of scandal. Lanham, Md.: Rowman \& Littlefield Publishers.

Salter, L. (2015). Framing Glenn Greenwald: Hegemony and the NSA/GCHQ surveillance scandal in a news interview. International Journal of Media \& Cultural Politics, 11(2), 183-201. doi: 10.1386/macp.11.2.183_1

Schönbach, P. (2010). Account episodes : the management or escalation of conflict. Cambridge: Cambridge University Press.

Sedley, S. (1989). Public Inquiries: A Cure or a Disease? The Modern Law Review, 52(4), 469-479. doi: 10.1111/j.1468-2230.1989.tb02609.x

Seldon, A. (2009). Trust : how we lost it and how to get it back. London: Biteback.

Sherman, L. W. (1978). Scandal and reform : controlling police corruption. Berkeley: University of California Press.

Strange, S. (1996). The Retreat of the state : the diffusion of power in the world economy. New York: Cambridge University Press.

Thompson, J. B. (2000). Political scandal : power and visibility in the media age. Cambridge, Malden, Mass.: Polity Press, Blackwell. 
Tiffen, R. (1999). Scandals: Media, Politics and Corruption in Contemporary Australia Sydney: University of New South Wales Press.

Veggeland, N. (2009). Taming the regulatory state : politics and ethics. Cheltenham: Edward Elgar. Woffinden, B. (1987). Miscarriages of justice. London: Hodder \& Stoughton.

Young, J. (2007). The vertigo of late modernity. London: Sage.

Zerubavel, E. (2006). The elephant in the room : silence and denial in everyday life. Oxford; New York: Oxford University Press. 